\title{
Nursery and field growths of Enterolobium contortisiliquum seedlings produced in different containers and fertilizer doses
}

Thairini Claudino Zavistanovicz ${ }^{1}$, Ezequiel Gasparin ${ }^{1}$, Maristela Machado Araujo ${ }^{1} \oplus$, Alberto Cargnelutti Filho ${ }^{1}{ }^{\oplus}$, Suelen Carpenedo Aimi' ${ }^{1}$, Douglas Rodrigo Becker Foltz ${ }^{1}\left[\right.$, Daniele Urrutia Dorneles ${ }^{1}[0$

\footnotetext{
${ }^{1}$ Universidade Federal de Santa Maria, Santa Maria, RS, Brasil. E-mail: thairini.z@gmail.com; ezequiel.gasparin@ufsm.br; araujo.maristela@gmail.com; alberto.cargnelutti.filho@gmail.com; suaimi@gmail.com; douglasfoltz@gmail.com; danieleurrutia@yahoo.com.br
}

ABSTRACT: Studies on the early development of forest species usually only analyze their nursery growth, not taking the post planting into account. Therefore, this study aimed to evaluate the survival and growth under nursery and field conditions of Enterolobium contortisiliquum seedlings produced with different container volumes and controlled-release fertilizer (CRF) doses. The treatments were composed of two containers volumes $\left(110\right.$ and $\left.180 \mathrm{~cm}^{3}\right)$ with five CRF doses $\left(0 ; 3 ; 5 ; 7 ;\right.$ and $\left.9 \mathrm{~g} \mathrm{~L}^{-1}\right)$. At the nursery, at 150 days after sowing, the following attributes were evaluated: height $(\mathrm{H})$; stem diameter (SD); shoot (SDM), root (RDM) and total dry matter (TDM); and Dickson quality index (DQI). At 360 days after the field planting, the survival, $H$ and SD were measured. It was found interaction between factors for SD and significant effects of container volume for SDM, RDM, TDM and DQI. The maximum technical efficiency dose (MTED) of CRF in the nursery ranged from 6.50 to $9.74 \mathrm{~g} \mathrm{~L}^{-1}$. This allowed recommending the CRF dose for the fast seedling outplanting. The negative effects from base fertilization absence were identified on the seedlings field survival, yet there was no influence of the tested treatments on their growth 360 days after planting. For producing Enterolobium contortisiliquum seedlings, it is recommended using $110 \mathrm{~cm}^{3}$ containers with a CRF dose of $3 \mathrm{~g} \mathrm{~L}^{-1}$, which provides suitable performance on the outplanting and after it. However, doses above $7 \mathrm{~g} \mathrm{~L}^{-1}$ can reduce the seedlings nursery time in about six months after sowing.

Key words: controlled-release fertilizer; seedlings production; timbaúva; tubes

\section{Crescimento de mudas de Enterolobium contortisiliquum, em viveiro e a campo, produzidas em diferentes recipientes e doses de fertilizante}

RESUMO: Estudos abordando o desenvolvimento de espécies florestais na fase inicial de estabelecimento, via de regra, analisa apenas seu crescimento em viveiro, não considerando a fase de pós-plantio. Desse modo, este estudo objetivou avaliar a sobrevivência e o crescimento, em viveiro e a campo, de mudas de Enterolobium contortisiliquum produzidas com diferentes volumes de recipientes e doses de fertilizante de liberação controlada (FLC). Os tratamentos constituíram-se de dois volumes de recipientes (110 e $180 \mathrm{~cm}^{3}$ ) combinados com cinco doses de $\operatorname{FLC}\left(0,3,5,7\right.$ e $\left.9 \mathrm{~g} \mathrm{~L}^{-1}\right)$. No viveiro, aos 150 dias após 0 semeio, avaliaram-se a altura (H), o diâmetro do coleto (DC), as matérias secas da parte aérea (MSPA), radicular (MSR) e total (MST), e o índice de qualidade de Dickson (IQD). Aos 360 dias após o plantio no campo, avaliaram-se a sobrevivência, H e DC. Constatou-se a interação para DC, assim como o efeito do volume do recipiente na MSPA, MSR, MST e IQD. A dose de máxima eficiência técnica (DMET) de FLC em viveiro variou entre 6,50 e e 9,74 $\mathrm{g} \mathrm{L}^{-1}$. Isso permitiu inferir sobre a dose necessária para rápida expedição das mudas ao campo. Observou-se os efeitos negativos da ausência de adubação de base na sobrevivência das plantas no campo, porém não houve influência dos tratamentos testados sobre o crescimento das mudas após 360 dias do plantio. Na produção de mudas de Enterolobium contortisiliquum, a utilização do tubete de $110 \mathrm{~cm}^{3}$ conjuntamente com a dose de $3 \mathrm{~g} \mathrm{~L}^{-1}$ de FLC, proporcionam desempenho adequado das mudas no pós-plantio. Entretanto, doses superiores a $7 \mathrm{~g} \mathrm{~L}^{-1}$ podem acelerar a expedição das mudas do viveiro para cerca de seis meses após semeadura.

Palavras-chave: fertilização de liberação controlada; produção de mudas; timbaúva; tubetes 


\section{Introduction}

Techniques for producing seedling and managing commercial plantations in Brazil, with species from the Eucalyptus and Pinus genera, have become a benchmark model due to the investments in research and development of new production technologies. This model can be useful in improving the production process of native species with both economic and environmental potential.

Among the forest species with the multiple-use possibility, the Enterolobium contortisiliquum (Vell.) Morong (Fabaceae) stands out, popularly known in Brazil as timbaúva, orelha-demacaco, timboril, pau-sabão (Carvalho, 2003) or as Pacara Earpod Tree over North America. The species naturally occurs throughout Brazil, Bolivia, Paraguay, Argentina and Uruguay (Grings \& Brack, 2011), since it has high ecological plasticity and is classified as a pioneer and heliophile, standing out for its rapid growth (Backes \& Irgang, 2009). Its lumber or its roundwood are recommended for shipbuilding, manufacturing toys and hive boxes (Carvalho, 2003), also used in mixed reforestation and recovery of areas, except in excessively humid environments (Saueressig, 2014).

However, even the species with broad adaptation capacity need to have their ecology and silviculture known for determining the best form of cultivation and management to be employed. The outplanting is decisive, and failures during the forest implantation are common due to the low morphophysiological quality of seedlings, the use of inadequate techniques in the implantation, and the actual planting itself (Campoe et al., 2014).

It is of utmost importance using quality seedlings when establishing forest stands, as they will directly influence the survival and growth in the field (Davide et al., 2015; Araujo et al., 2018). When determining this quality, the morphological characteristics (based on phenotypic aspects) are still the most used, since they have a greater acceptance by nurserymen, in addition to their practical measurement. Yet, quality attributes definitions that may suggest greater survival and initial growth are still required, especially in the face of the adversities found in field after the outplanting (Eloy et al., 2013).

Choosing the container for producing the seedlings is associated with the time that they will remain at the nursery, as well as the growth rate of the species, the desired size, the used production system and the planting purpose. Seedlings produced in larger volume containers have advantages, such as a higher root/shoot ratio and greater biomass (Close et al., 2010). In the case of Eucalyptus urograndis seedlings produced in tubes of 53 and $180 \mathrm{~cm}^{3}$, the container volume did not influence the growth at 12 months after the outplanting (Correia et al., 2013). It can be inferred from this that the container volume effect is more determinant in the initial stage of the seedling establishment, as plants with an adequate root/shoot ratio are able to withstand adverse field conditions, thus increasing their survival rate.

Another important consideration aspect is the use of fertilizers. The native species from the Atlantic Forest, for example, have different nutritional requirements and because of this, establishing guidelines for the fertilization planning is a necessity. This has fundamental importance in producing seedlings of good silvicultural quality, as it relates to the survivability and growth after the outplanting (Cruz et al., 2006). Commercial substrates are, overall, inefficient in providing nutrients during the cultivation, thus making the basic fertilization to be used in combination with top dressing (Oliet et al., 1999).

Using controlled-release fertilizers is prominent in the nursery seedling production, as these facilitate the management and can contribute to a greater growth due to the way nutrients are released, also being a subject widely studied (Aimi et al., 2016; Gasparin et al., 2017; Navroski et al., 2018). Futhermore, the controlled-release fertilizers (CRF) are primarily used in the fertilization of plants grown in tubes, as these containers have a greater nutrient leaching and it is economically interesting to have more control over this release (Davide et al., 2015). However, in addition to defining the best fertilizer type, the most effective dose for the each species growth must also be analyzed.

In light of the foregoing, further studying the seedlings performance after outplanting is required, since this type of information is usually ignored (Abreu et al., 2015; Rorato et al., 2018). Therefore, this study aimed to evaluate the survival and growth, both in nursery and in field, of Enterolobium contortisiliquum seedlings produced with different container volumes and controlled-release fertilizer doses.

\section{Materials and Methods}

\section{Seedling production}

The experiment was conducted in a greenhouse at the Silviculture and Forestry Laboratory from the Federal University of Santa Maria (latitude 29 $43^{\prime} 11.867^{\prime \prime} S$; longitude $\left.53^{\circ} 43^{\prime} 14.009^{\prime \prime} \mathrm{W}\right)$. Seeds were collected from $16 \mathrm{E}$. contortisiliquum trees, 100 meters apart one another, located in remnants of Deciduous Seasonal Forest, Santa Maria, Rio Grande do Sul. After collection, the fruits were taken to the Forest Nursery for seed extraction, where they were dried in an oven at $30{ }^{\circ} \mathrm{C}$ for about 48 hours in order to facilitate removing their seeds manually. Before sowing, the physical dormancy of the seeds was overcome by manually sanding them on the opposite side of their micropyle (Brazil, 2013). Afterwards, the containers were filled with substrate and two seeds sowed in each one. The emergence was of $95 \%$ and, subsequently, the thinning performed left only one seedling per container.

Ten treatments were evaluated, formed by the combination of two tube volumes (110 and $180 \mathrm{~cm}^{3}$ ) and five controlledrelease fertilizer (CRF) doses $\left(0 ; 3 ; 5 ; 7\right.$; and $9 \mathrm{~g} \mathrm{~L}^{-1}$ of substrate) in the base fertilization. The substrate used was the lowretention Carolina Soil ${ }^{\circ}$, composed of peat, vermiculite and $20 \%$ of carbonized rice husk. A randomized block design was used, with four replicates. Each of the 40 experimental units (plots) were composed by polypropylene trays containing 24 tubes. 
The basic fertilization applied with CRF had $18 \% \mathrm{~N}$, with 9.5\% and $8.5 \%$ of it in the ammoniacal and nitrate forms, respectively; $5 \%$ of $\mathrm{P}_{2} \mathrm{O}_{5}$ and $9 \%$ of $\mathrm{K}_{2} \mathrm{O}$, in granular form, coated with a semipermeable organic resin. From 21 days after sowing until the experiment ending, all treatments were weekly top dressed with the Peter's Professional ${ }^{\circledR}$ fertilizer in the $5 \mathrm{~g} \mathrm{~L}^{-1}$ dosage (macronutrients - 9.0\% N; 45.0\% $\mathrm{P}_{2} \mathrm{O}_{5}, 15.0 \% \mathrm{~K}_{2} \mathrm{O} ; 1.0 \%$ $\mathrm{Mg}$; and micronutrients - $0.0088 \% \mathrm{~B} ; 0.0036 \% \mathrm{Cu} ; 0.05 \% \mathrm{Fe}$; $0.025 \% \mathrm{Mn} ; 0.0009 \% \mathrm{Mo}$; and $0.0025 \% \mathrm{Zn}, 69 \%$ salinity index, $69.3 \mathrm{mS} \mathrm{cm}^{-1}$ of electrical conductivity and $4.42 \mathrm{pH}$ in water, according to the information provided by the manufacturer).

At 150 days after sowing (DAS), the shoot height $(H)$ was measured with a ruler $(\mathrm{cm})$, and the stem diameter (SD) with a digital caliper $(\mathrm{mm})$, in the six central plants from each plot, in order to avoid possible border interference. Subsequently, the seedlings were split in shoot and root system, this last one later washed with running water on sieves, in order to avoid material loss. Afterwards, the plant material was put in paper bags and oven dried at $65{ }^{\circ} \mathrm{C}$, until reaching constant weight, thus obtaining the dry matter values from the shoot (SDM), root (RDM) and the total (TDM). Futhermore, the Dickson quality index (DQI) (Dickson et al., 1960) was calculated as according to Equation 1.

$$
\mathrm{DQI}=\frac{\operatorname{TDM}(\mathrm{g})}{\left[\left(\frac{\mathrm{H}(\mathrm{cm})}{\mathrm{SD}(\mathrm{mm})}\right)+\left(\frac{\mathrm{SDM}(\mathrm{g})}{\mathrm{RDM}(\mathrm{g})}\right)\right]}
$$

In which : Dickson quality; TDM = total dry matter in $\mathrm{g} ; \mathrm{H}=$ shoot height in $\mathrm{cm}$; $\mathrm{SD}=$ stem diameter in $\mathrm{mm} ; \mathrm{SDM}=$ shoot dry matter in g; RDM = root dry matter in $\mathrm{g}$.

\section{Field planting}

Planting was at the end of July, conducted in a randomized block design with four blocks, each composed by four seedlings per replicate for each treatment, thus totaling 160 seedlings. Considering their mean height, the central seedlings from each plot under evaluation at the nursery for outplanting were then selected. The used treatments were the same (containers $x$ doses) as previously described.

The experiment was set up in a reduced spacing of $1 \mathrm{~m} \times 1$ $m$ between seedlings, with only the initial out-planting analysis as the objective. Pits were opened with approximately $0.35 \mathrm{mx}$ $0.35 \mathrm{~m} \times 0.35 \mathrm{~m}\left(0.043 \mathrm{~m}^{3}\right)$, aiming at the loosening of the soil. These pits were then filled up with subsoil soil mixed with the commercial organic substrate Policultura Rosa (bio-stabilized organic compound based on rice ash and barley residue) in a 1:1 ratio. The soil chemical characterization was held at the Soil Analysis Laboratory (UFSM), employing the methodology described in Tedesco et al. (1995), thus demonstrating a low fertility soil (Table 1). Thereby, the organic substrate mixed with the soil provided increased $\mathrm{pH}$, organic matter and, consequently, macro and micronutrients.

At 120 and 240 days after planting, two top-dressing fertilizations were performed with controlled-release fertilizer (NPK, 05-20-20), at the 100 grams per plant dosage. During the experiment conduction, ants and weed were controlled routinely with hoeing around the seedlings and the mechanical weeding of the rows and between them. Survival (S) evaluations were performed at 30, 180 and 360 days after planting and $\mathrm{H}$ and SD were measured at 360 days.

\section{Data analysis}

First, the normality of the errors and the homogeneity of the data variances was verified through the ShapiroWilk (Shapiro \& Wilk, 1965) and Bartlett (Bartlett, 1937) tests, respectively. Then, the analysis of variance and $F$ test at $5 \%$ probability were performed, having no need for data transformation. The means were compared with the Tukey and Scott Knott tests and/or the polynomial regression at 5\%, with the data analyzed according to the following model: $Y_{\mathrm{ijk}}=$ $m+b_{k}+a_{i}+d_{j}+(a d)_{i j}+\varepsilon_{i j k}$. In which: $Y_{i j k}$ is the observed value for each evaluated plant; $m$ is a constant; $b_{k}$ is the random effect from block $k$; $a_{i}$ is the effect of the i level container size; $d_{j}$ is the effect of the $j$ level dose of controlled-release fertilizer; $\mathrm{ad}_{\mathrm{ik}}$ is the effect of the interaction between container size and controlled-release fertilizer dose; and $\varepsilon_{\mathrm{ijk}}$ is the experimental error. The maximum technical efficiency dose (MTED) was determined through the Equation 2.

$$
x=\frac{-b_{1}}{\left(2 b_{2}\right)}
$$

In which: $x=$ maximum technical efficiency point; $b_{1}$ and $b_{2}=$ first-degree and second-degree coefficients of the equation.

\begin{tabular}{|c|c|c|}
\hline Attributes & Values & Classifications $^{1}$ \\
\hline Organic matter $(\mathrm{m} / \mathrm{v})$ & 2.1 & Low \\
\hline Base saturation $\left(\mathrm{g} \mathrm{kg}^{-1}\right)$ & 349 & - \\
\hline $\mathrm{pH}$ in $\mathrm{H}_{2} \mathrm{O}(1: 1)$ & 4.5 & Very low \\
\hline 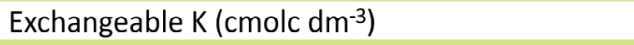 & 0.04 & Very low \\
\hline Exchangeable $\mathrm{Ca}\left({\left.\mathrm{cmolc} \mathrm{dm}^{-3}\right)}^{-3}\right.$ & 2.1 & Medium \\
\hline Exchangeable $\mathrm{Al} \mathrm{cmolc} \mathrm{dm}^{-3}$ ) & 0.7 & - \\
\hline Cation exchange capacity at $\mathrm{pH} 7.0\left(\mathrm{cmolc}^{-3} \mathrm{~m}^{-3}\right)$ & 16.8 & High \\
\hline
\end{tabular}

Table 1. Soil chemical attributes of the Enterolobium contortisiliquum planting area, Santa Maria, RS, Brazil.

(1) Classification according to SBCS/CQFS (2004). 
Statistical analyzes were performed with the aid of the Sisvar 5.6 software (Ferreira, 2014) and an electronic spreadsheet.

\section{Results and Discussion}

\section{Nursery growth}

Among the evaluated variables at 150 DAS $(H, S D, S D M$, RDM, TDM and DQI), an interaction between the tubes and doses ( $p \leq 0.05$ ) was found only for SD. In general, the results demonstrate that the evaluated factors interfere with the seedling growth in an independent manner, similar to what Cargnelutti Filho et al. (2012) verified for Cabralea canjerana (Vell.) Mart seedlings.

It was observed that $\mathrm{H}$ did not present any significant difference when produced in different containers, having a mean value of $16.90 \mathrm{~cm}$ (Table 2). SD was influenced by the interaction between the factors, with difference only observed on the plants grown in the $110 \mathrm{~cm}^{3}$ tube and CRF doses of 3 and $5 \mathrm{~g} \mathrm{~L}^{-1}$, which had lower means. Based on the outplanting indicators, characterizing $\mathrm{H}$ between 20.0 and $35.0 \mathrm{~cm}$ and SD between 3.0 and $10.0 \mathrm{~mm}$ (Gonçalves et al., 2005; Davide \& Faria, 2008), in the highest CRF doses $\left(\cong 7 \mathrm{~g} \mathrm{~L}^{-1}\right)$ used, regardless of the container volume, the seedlings attained adequate mean height and stem diameter values. This corresponds to the assumption that taller seedlings are able to compete with weeds, capturing greater solar radiation and having a direct effect on photosynthesis net gain (Grossnickle, 2012).

Taking the means of SDM, RDM, TDM and DQI (Table 2) into account, there was no interaction between the tested factors (container volume $x$ CRF dose). For these same variables, however, growth means about $15 \%$ higher were observed in the seedlings produced in the $180 \mathrm{~cm}^{3}$ tubes, in relation to those from the $110 \mathrm{~cm}^{3}$ ones, having values of $2.26 \mathrm{~g}$ for SDM; $3.34 \mathrm{~g}$ for RDM and $5.59 \mathrm{~g}$ for TDM.
The DQI had the highest value with the $180 \mathrm{~cm}^{3}$ tube, having an overall mean of 2.79. Evaluating this parameter is important because its calculation contemplates the biomass distribution balance in the plant, considering the results from several morphological attributes used for evaluating the seedling quality (Medeiros et al., 2018).

Seedlings with a balanced shoot-root ratio biomass can have better performance in water-deficit sites (Pinto et al., 2011). Despite its importance, Afonso et al. (2012) point out that the DQI varies between species and cultivation systems, and the recommended value for a given genotype is not necessarily ideal for others, thus rendering research as essential when evaluating individual species.

When analyzing several forest species, Araujo et al. (2018) found adequate DQI values ranging from 0.07 to 2.91, also considering the different production methods and supplies used in each case. For producing E. contortisiliquum seedlings, under the conditions evaluated in the present study, it can be inferred that the mean DQI values are within the range considered as the standard regarding seedling quality for native species, as recommended by Araujo et al. (2018).

Although it is not the object of this study, when choosing the container type among the most growth-favorable options, the available physical space must be considered, as well as the financial investment and the seedlings production time up to the outplanting, as larger volume containers require more space and resources but also allow the seedlings to remain at the nursery longer (Davide \& Faria, 2008). Therefore, defining the type and volume of the container to be used is a determining factor during the planning phase of the seedling production.

MTED had approximate means for the analyzed variables, from 6.50 to $9.74\left(\mathrm{~g} \mathrm{~L}^{-1}\right.$ ) (Table 3). These data allow us to infer that, under the tested conditions, CRF doses lower than 6.50 $\mathrm{g} \mathrm{L}^{-1}$ are unfavorable to the growth of $E$. contortisiliquum

Table 2. Means of the shoot height $(H)$, stem diameter (SD), shoot dry matter (SDM), root dry matter (RDM), total dry matter (TDM) and Dickson quality index (DQI) of $E$. contortisiliquum seedlings evaluated at 150 DAS, according to two tube volumes (110 and $\left.180 \mathrm{~cm}^{3}\right)$ and five controlled-release fertilizer doses $\left(0 ; 3 ; 5 ; 7\right.$; and $9 \mathrm{~g} \mathrm{~L}^{-1}$ of substrate).

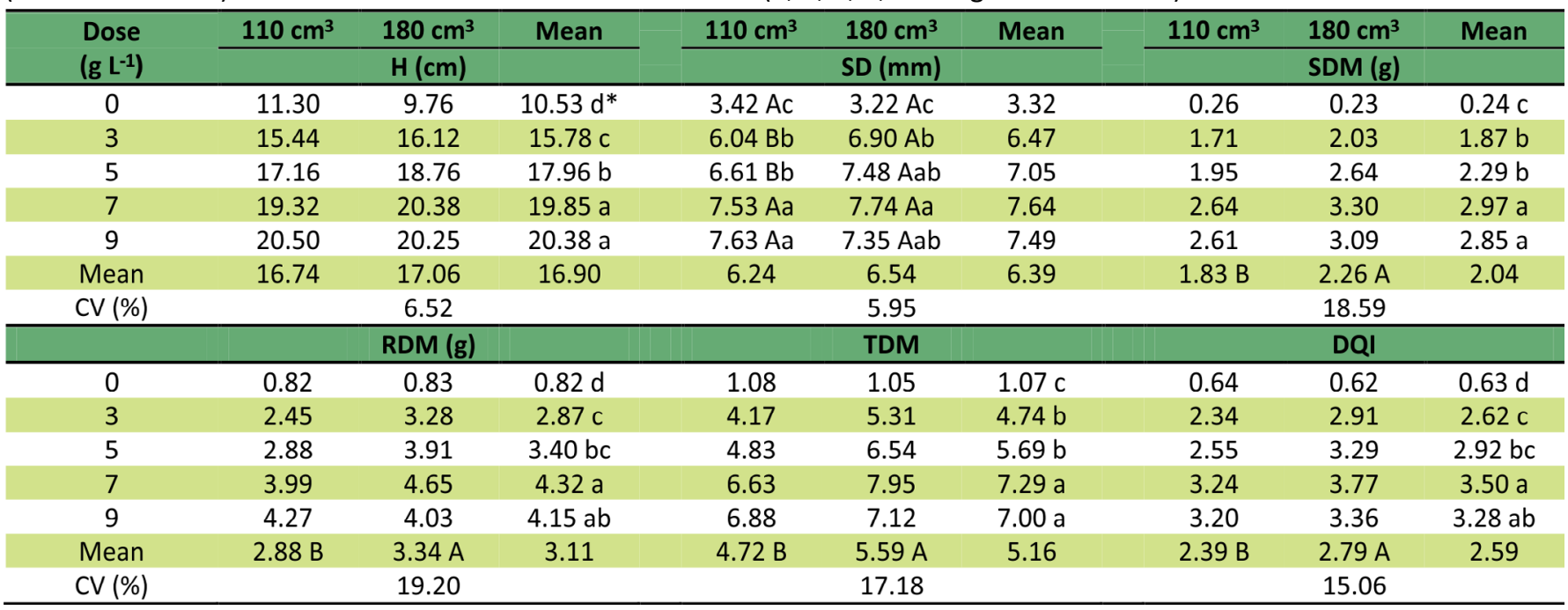

* In each variable, means not followed by the same uppercase letter in the row and lowercase in the column differ by the Tukey test at the $5 \%$ probability level. 
Table 3. Estimate of the quadratic equations parameters $\left(Y=a+b x+c x^{2}\right)$, coefficient of determination $\left(R^{2}\right)$ and maximum technical efficiency dose (MTED) of the variables shoot height (H), in $\mathrm{cm}$, stem diameter (SD), in mm, shoot dry matter (SDM), in g, root dry matter (RDM), in g, total dry matter (TDM), in g and Dickson quality index (DQI) of E. contortisiliquum seedlings, in function of five controlled-release fertilizer (CRF) doses $\left(0 ; 3 ; 5 ; 7\right.$; and $9 \mathrm{~g} \mathrm{~L}^{-1}$ of substrate) for two tube volumes (110 and 180 $\mathrm{cm}^{3}$ ) at 150 days after sowing.

\begin{tabular}{ccccccc}
\hline Variable $(\mathbf{Y})$ & Tube $\left(\mathbf{c m}^{\mathbf{3}}\right)$ & $\mathbf{A}$ & $\mathbf{B}$ & $\mathbf{c}$ & $\mathbf{R}^{\mathbf{2}}$ & MTED (g L-1) \\
\hline H & & \multicolumn{3}{c}{$\mathbf{1 5 0}$ days after sowing } & & \\
\hline SD & 110 and 180 & 10.532145 & 2.042787 & -0.104828 & 99.91 & 9.74 (maximum) \\
SD & 110 & 3.469660 & 0.946462 & -0.053898 & 99.01 & 8.78 (maximum) \\
SDM & 180 & 3.322224 & 1.412416 & -0.108564 & 98.73 & 6.50 (maximum) \\
RDM & 110 and 180 & 0.249362 & 0.627862 & -0.037154 & 98.83 & 8.45 (maximum) \\
TDM & 110 and 180 & 0.827881 & 0.787822 & -0.045663 & 98.58 & 8.63 (maximum) \\
DQI & 110 and 180 & 1.077243 & 1.415683 & -0.082817 & 98.69 & 8.55 (maximum) \\
\hline
\end{tabular}

seedlings and, therefore, should be avoided when nurserymen wish to hasten the outplanting (less than six months). When deciding on a longer outplanting period, they must continue top dressing the seedlings, aiming the nutrient releasing in six months, as estimated by the manufacturer.

It is noteworthy stating that the top dressing may have provided a compensatory effect on the nutrient supply the seedling growth. The applied foliar fertilization, as it has higher soluble doses of $\mathrm{P}$ and $\mathrm{K}$ compared to the base fertilization, may have favored the development, especially in treatments with lower CRF doses. Several factors influence the nutrient absorption by the leaves, such as the cuticular layer characteristics, the pore density, environmental conditions, leaf age, and others (Marenco \& Lopes, 2009).

Among the analyzed variables, $\mathrm{H}$ had a higher MTED than the others $\left(9.74 \mathrm{~g} \mathrm{~L}^{-1}\right)$, demonstrating the favorable effect of the highest tested dose for seedling height growth. Dumroese et al. (2011) also evidenced such effect, when Acacia koa seedlings demonstrated a significant increase in shoot height with the CRF addition (15-09-12). Afonso et al. (2012) attribute the greater $\mathrm{H}$ growth in $E$. contortisiliquum plants, produced in a substrate free if organic matter, to the CRF effect (1509-12, $8 \mathrm{~g} \mathrm{~L}^{-1}$ dose), which continuously provided nutrients, thus minimizing the possibility of nutritional deficiencies happening during the seedling formation period.

Polymer-coated fertilizers are considered as efficient in the controlled-release category, widely used in plant production (Jacobs \& Landis, 2009; Navroski et al., 2018). If compared to soluble fertilizers, the CRF can overcome problems such as increased mortality due to the high salt concentration in the rooting zone (Fan et al., 2004). This may have contributed, even in the highest CRF dose tested in the present study $(9 \mathrm{~g}$ $\mathrm{L}^{-1}$ ), to the no register of toxicity symptoms in the seedlings, which were, on the contrary, quite vigorous plants.

Regarding SDM, RDM, TDM and DQI at 150 DAS, MTED of 8.45; 8.63; 8.55; and $7.55 \mathrm{~g} \mathrm{~L}^{-1}$ were found, respectively, for each variable (Table 3 ). These obtained results demonstrate the need for studies that identify the ideal fertilizer dose for other forest species, aiming to optimize their nutrition, by favoring growth and reducing fertilization costs. For that matter, Gasparin et al. (2015) observed a $9.0 \mathrm{~g} \mathrm{~L}^{-1}$ dose (18-59 NPK) for Parapiptadenia rigida (Benth.) Brenan, while Aimi et al. (2016) and Berghetti et al. (2016) found doses of 11.5 $\mathrm{g} \mathrm{L}^{-1}$ (15-9-12 NPK) and 7.5 g L-1 (15-09-12 NPK), respectively, for the species Cabralea canjerana (Vell.) Mart. and Cordia trichotoma (Vell.) Arrab. Ex Steud.

Seedlings produced from the above mentioned doses are more quickly outplanted, within the indicators ( $H$ and SD) described in the literature. Specifically for $E$. contortisiliquum, the outplanting can occur in about six months, when produced in the highest doses. On this occasion, visually, they also demonstrate greater vigor, possibly tolerating weed competition problems. On the other hand, the cost increase of the input (CRF) at the nursery is recognized, with the person in charge being entitled of evaluating the use of lower doses, with greater supplementation by top-dressing fertilization (greater labor) or the increased CRF dose.

\section{Seedlings outplanting}

Regarding the variable survival of $E$. contortisiliquum seedlings, evaluated at 30,180 and 360 days after field planting; there was no interaction between the evaluated factors, as well as differences in $\mathrm{H}$ and SD at 360 days (Table 4). Survival and growth of the seedlings in field is extremely important, as it serves as a basis for planning future forest plantations, both for commercial purposes and for restoration. In both cases, knowing the behavior of tree species after the planting is required, aiming to use techniques that reduce mortality (Rorato et al., 2018). This must be emphasized with native species, such as the $E$. contortisiliquum, which is commonly used in restoration plantations, often with maintenance and conduction practices which are precarious and limiting for the forest formation.

As according to Belloto (2010), mortality rates above $10 \%$ in plantations with native species require immediate interventions. In this study, interventions (fertilization, weed competition and ants control) were held for seedlings produced in both containers, and even with the common practices used in the commercial species silviculture, after 180 days of field planting (Table 4), the average mortality was

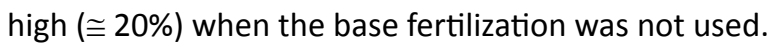

The lowest field survival occurred in seedlings produced with no fertilization ( $0 \mathrm{~g} \mathrm{~L}^{-1}$ dose), differing from the other treatments in the first 30 days after planting $(78.1 \%$ of 
Table 4. Survival (S) percentage at 30, 180 and 360 days after field planting; shoot height (H), in cm, and stem diameter (SD), in $\mathrm{mm}$, of Enterolobium contortisiliquum seedlings at 360 days after field planting, according to two tube volumes (110 and 180 $\mathrm{cm}^{3}$ ) and five controlled-release fertilizer (CRF) doses (0; 3; 5; 7; and $9 \mathrm{~g} \mathrm{~L}^{-1}$ of substrate).

\begin{tabular}{|c|c|c|c|c|c|}
\hline \multirow{3}{*}{$\begin{array}{l}\text { Tube } \\
\left(\mathrm{cm}^{3}\right)\end{array}$} & $\mathbf{S}$ & 5 & $S$ & \multirow{2}{*}{$\begin{array}{c}\mathrm{H} \\
(\mathrm{cm})\end{array}$} & \multirow{2}{*}{$\begin{array}{c}\mathrm{SD} \\
(\mathrm{mm})\end{array}$} \\
\hline & \multicolumn{3}{|c|}{$(\%)$} & & \\
\hline & 30 days after planting & 180 days after planting & \multicolumn{3}{|c|}{360 days after planting } \\
\hline 110 & $92.5 a^{*}$ & $76.2 \mathrm{a}$ & $76.2 \mathrm{a}$ & $158.91 \mathrm{a}$ & $39.31 \mathrm{a}$ \\
\hline 180 & $97.5 \mathrm{a}$ & $81.2 \mathrm{a}$ & $81.2 \mathrm{a}$ & $174.80 \mathrm{a}$ & $40.59 \mathrm{a}$ \\
\hline \multirow{2}{*}{$\begin{array}{l}\text { Dose } \\
\left(\mathrm{g} \mathrm{L}^{-1}\right) \\
\end{array}$} & $S$ & $S$ & $S$ & \multirow{2}{*}{$\begin{array}{c}\mathrm{H} \\
(\mathrm{cm}) \\
\end{array}$} & \multirow{2}{*}{$\begin{array}{c}\text { SD } \\
(\mathrm{mm}) \\
\end{array}$} \\
\hline & & $(\%)$ & & & \\
\hline 0 & $78.1 b^{*}$ & $6.2 \mathrm{~b}$ & $6.2 \mathrm{~b}$ & $139.50 \mathrm{a}$ & $36.87 \mathrm{a}$ \\
\hline 3 & $100.0 \mathrm{a}$ & $100.0 \mathrm{a}$ & $100.0 \mathrm{a}$ & $173.52 \mathrm{a}$ & $41.11 \mathrm{a}$ \\
\hline 5 & 96.9 a & $90.6 \mathrm{a}$ & $90.6 a$ & $153.51 \mathrm{a}$ & $35.52 \mathrm{a}$ \\
\hline 7 & $100.0 \mathrm{a}$ & $100.0 \mathrm{a}$ & $100.0 \mathrm{a}$ & $181.11 \mathrm{a}$ & $42.67 \mathrm{a}$ \\
\hline 9 & $100.0 \mathrm{a}$ & $96.9 \mathrm{a}$ & 96.9 a & $186.64 \mathrm{a}$ & $43.57 \mathrm{a}$ \\
\hline CV (\%) & 12.25 & 12.96 & 12.96 & 31.48 & 19.62 \\
\hline
\end{tabular}

* Means not followed by the same letter in the column differ by the Scott-Knott test at the $5 \%$ probability level.

survival) and intensifying in the subsequent evaluations (6.2\% of survival). The mortality of these seedlings after planting proves that the successful forest implantation is directly related to the quality of the used seedlings, considering that the plant vigor is associated with the base fertilization during the production phase at the nursery, which can cause high field mortality (Table 4). Base fertilization has a fundamental role in the nutrition of seedlings by supplying nutrients for their formation and growth, and it should be considered in a way that there is no damage to the plant growth due to a nutrient deficiency (Gonçalves et al., 2005). This can be achieved by different fertilization forms, compliant to the species demand and the availability of labor and resources (Navroski et al., 2018).

Therefore, when striving for successful forest plantations with E. contortisiliquum, it is essential that the seedlings receive base fertilization ( $3 \mathrm{~g} \mathrm{~L}^{-1}$ of $\mathrm{CRF}$ ) incorporated into the substrate. It is also noteworthy that the species has the potential for rapid establishment, even when produced with reduced fertilizer doses. The variables $\mathrm{H}$ and SD corroborate with the results found at the nursery phase (Tables 2 and 3 ), with no effect of containers $\left(110\right.$ and $\left.180 \mathrm{~cm}^{3}\right)$ and fertilizer doses at 360 days after planting.

The non-significant influence of the container volumes on the timbaúva seedlings growth was similar to the results found by Malavasi \& Malavasi (2006), on seedlings from Cordia trichotoma and Jacaranda micranta. These authors observed that, 180 days after the field planting, the seedlings produced in different tube sizes $\left(120,180\right.$ and $\left.300 \mathrm{~cm}^{3}\right)$ all demonstrated a similar behavior among themselves, although superior to the one having the lowest volume $\left(55 \mathrm{~cm}^{3}\right)$.

As for the fertilization with controlled-release fertilizer, albeit having maximum technical efficiency with a dose close to $9 \mathrm{~g} \mathrm{~L}^{-1}$, for most variables, it was found that lower doses (3 to $5 \mathrm{~g} \mathrm{~L}^{-1}$ ) can also be used, since they have similar survival and growth at the nursery and 360 days after planting. The possibility of the used organic compost, in the pits, positively influencing the results must be considered, especially in treatments with lower doses. This would represent the high potential of the species in establishing itself even in face of soil loosening and nutrient availability.

While still at the nursery, it become evident that the evaluated treatments must also be analyzed under field conditions, since, in the present study, the responses during seedling production allow for decisions during this phase that will not necessarily correspond to the responses in field.

During the planting, the behavior changes during plant growth are not discarded, when grown with higher CRF doses. However, the reduced initial spacing between plants (1 $\mathrm{m} \mathrm{x}$ $1 \mathrm{~m}$ ) would be inadequate in obtaining such responses in a longer time, since superior treatments would quickly undergo a self-thinning and thus compromise the results. The initial planting phase must be conducted with well-established cultural practices, having as goal the increased survival gains and, consequently, yield, thus reducing costs in turn. With this in mind, it is believed that the growth of smaller seedlings, as observed in treatments with lower doses $\left(<7 \mathrm{~g} \mathrm{~L}^{-1}\right)$, may have been enhanced by the cultural practices used in the present research, such as soil loosening, fertilization and controlling the weed competition and ants.

Additional studies should be conducted in order to check for other container types, as well as other fertilization sources, including in the field planting, since it would result in saving resources. Moreover, studies related to the timbaúva physiology, such as mechanisms and absorption speed, as well as nutritional demand, are important in complementing the silviculture of the species.

\section{Conclusion}

During the production of Enterolobium contortisiliquum seedlings, using $110 \mathrm{~cm}^{3}$ tubes together with the $3 \mathrm{~g} \mathrm{~L}^{-1}$ dose of the controlled-release fertilizer allow the adequate growth of the seedlings in field.

Doses greater than $7 \mathrm{~g} \mathrm{~L}^{-1}$ can accelerate the seedlings outplanting in about six months after their sowing. 


\section{Literature Cited}

Abreu, A.H.M.; Leles, P.S.S.; Melo, L. A.; Ferreira, D. A. A.; Monteiro, F. A. S. Produção de mudas e crescimento inicial em campo de Enterolobium contortisiliquum produzidas em diferentes recipientes. Revista Floresta, v.45, n.1, p. 141-150, 2015. https:// doi.org/10.5380/rf.v45i1.28931.

Afonso, M.V.; Martinazzo, E.G.; Aumonde, T.Z.; Villela, F.A. Composição do substrato, vigor e parâmetros fisiológicos de mudas de timbaúva (Enterolobium contortisiliquum (Vell.) Morong). Revista Árvore, v.36, n.6, p.1019-1026, 2012. https:// doi.org/10.1590/S0100-67622012000600003.

Aimi, S.C.; Araujo, M.M; León, E.B; Oliveira, G.G. de; Cunha, F.S. Volumen de contenedores y dosis de fertilizante de liberación controlada en el crecimiento de plantas de Cabralea canjerana producidas en vivero. Bosque, v.37, n.2, p.401-407, 2016. https:// doi.org/10.4067/S0717-92002016000200018.

Araujo, M. M.; Navroski, M. C.; Schorn, L. A.; Tabaldi, L. A.; Rorato, D. G.; Turchetto, F.; Zavistanovicz, T. C.; Berghetti, A. L. P.; Aimi, S. C.; Tonetto, T. da S.; Gasparin, E.; Dutra, A. F.; Mezzomo, J. C.; Gomes, D. R.; Griebeler, A. M.; Silva, M. R. da; Barbosa, F. M.; Lima, M. S. de. Caracterização e análise de atributos morfológicos e fisiológicos indicadores da qualidade de mudas em viveiro florestal. In.: Araújo, M.M.; Navroski, M.C.; Schorn, L.A. (Orgs.). Produção de sementes e mudas: um enfoque à Silvicultura. Santa Maria: Ed. UFSM, 2018. Cap. 16, p. 345-365.

Backes, P.; Irgang, B. Árvores do Sul: guia de identificação e interesse ecológico. Santa Cruz do Sul: Instituto Souza Cruz, 2002. 326 p.

Bartlett, M.S. Properties of sufficiency and statistical tests. Proceedings of the Royal Society of London, Serie A, v.160, p.268282, 1937. https://doi.org/10.1098/rspa.1937.0109.

Belloto, A. Monitoramento das áreas restauradas como ferramenta para avaliação da efetividade das ações de restauração e para redefinição metodológica. In: Rodrigues, R.R.; Brancalion, P.H.S.; Isernhagem, I. (Eds.). Pacto pela restauração da mata atlântica: referencial dos conceitos e ações de restauração florestal. São Paulo: LERF/ESALQ, 2010. 256 p.

Berghetti, Á.L.P., Araujo, M.M.; Tonetto, T.S.; Aimi, S.C.; Navroski, M.C.; Turchetto, F.; Zavistanovicz, T.C. Growth of Cordia trichotoma seedlings in different sizes of recipients and doses of fertilizer. African Journal of Agricultural Research, v.28, n.11, p. 2450-2455, 2016. https://doi.org/10.5897/AJAR2016.10883.

Brasil. Ministério da Agricultura, Pecuária e Abastecimento. Instruções para análise de espécies florestais. Brasília: MAPA/ ACS, 2013. 98p.

Campoe, O.C.; lannelli, C.; Stape, J.L.; Cook, R.L.; Mendes, J.C.T.; Vivian, R. Atlantic forest tree species responses to silvicultural practices in a degraded pasture restoration plantation: from leaf physiology to survival and initial growth. Forest Ecology and Management, v.313, p.233-242, 2014. https://doi.org/10.1016/j. foreco.2013.11.016.

Cargnelutti Filho, A.; Araujo, M.M.; Gasparin, E.; Avila, A.L. Dimensionamento amostral para avaliação de altura e diâmetro de mudas de Cabralea canjerana. Ciência Rural, v.42, n.7, p.1204-1211, 2012. https://doi.org/10.1590/s010384782012000700011 .
Carvalho, P.E.R. Espécies arbóreas brasileiras. v.1. Brasília, DF: Embrapa Informação Tecnológica, 2003. 593 p.

Close, D.C.; Paterson, S.; Corkrey, R.; Mcarthur, C. Influences of seedling size, container type and mammal browsing on the establishment of Eucalyptus globulus in plantation forestry. New Forests, v.39, n.1, p.105-115, 2010. https://doi.org/10.1007/ s11056-009-9158-3.

Correia, A.C.G.; Santana, R.C.; Oliveira, M.L.R.; Titon, M.; Ataíde, G.M.; Leite, F.P. Volume de substrato e idade: influência no desempenho de mudas clonais de eucalipto após replantio. Cerne, v. 19, n. 2, p. 185-191, 2013. https://doi.org/10.1590/ S0104-77602013000200002.

Cruz, C.A.F. e; Paiva, H.N. de; Guerrero, C.R.A. Efeito da adubação nitrogenada na produção de mudas de sete-cascas (Samanea inopinata (Harms) Ducke). Revista Árvore, v.30, n.4, p.537-546, 2006. https://doi.org/10.1590/S0100-67622006000400006.

Davide, A.C. et al. Fatores que afetam a qualidade de mudas destinadas aos projetos de restauração de ecossistemas florestais. In.: Davide, A.C; Botelho, S.A (Eds.). Fundamentos e métodos de restauração de ecossistemas florestais: 25 anos de experiência em matas ciliares. Lavras: Ed. UFLA, 2015. p.181-274.

Davide, A.C.; Faria, J.M.R. Viveiros florestais. In: Davide, A.C.; Silva, E.A.A. (Eds.). Produção de sementes e mudas de espécies florestais. Lavras: UFLA, 2008. p.83-124.

Dickson, A.; Leaf, A.; Hosner, J.F. Quality appraisal of white spruce and white pine seedling stock in nurseries. Forest Chronicle, v.36, n.1, p.10-13, 1960. https://doi.org/10.5558/tfc36010-1.

Dumroese, R.K.; Davis, A.S.; Jacobs, D.F. Nursery response of Acacia koa seedlings to container size, irrigation method, and fertilization rate. Journal of Plant Nutrition, v.34, n.6, p. 877-887, 2011. https://doi.org/10.1080/01904167.2011.544356.

Eloy, E.; Caron, B.O.; Schmidt, D.; Behling, A.; Schwers, L.; Elli, E.F. Avaliação da qualidade de mudas de Eucalyptus grandis utilizando parâmetros morfológicos. Floresta, v.43, n.3, p.373384, 2013. https://doi.org/10.5380/rf.v43i3.26809.

Fan, Z.; Moore, J.A.; Wenny, D.L. Growth and nutrition of containergrown ponderosa pine seedlings with controlled-release fertilizer incorporated in the root plug. Annals of Forest Science, v. 61, n.2, p. 117-124, 2004. https://doi.org/10.1051/forest:2004002.

Ferreira, D.F. Sisvar: A Guide for its Bootstrap procedures in multiple comparisons. Ciência e Agrotecnologia, v.38, n.2, p.109-112, 2014. https://doi.org/10.1590/S1413-70542014000200001.

Gasparin, E.; Araujo, M.M.; Saldanha, C.W.; Tolfo, C.V. Controlled release fertilizer and container volumes in the production of Parapiptadenia rigida (Benth.) Brenan seedlings. Acta Scientiarum. Agronomy, v.37, n.4, p.473-481, 2015. https://doi. org/10.4025/actasciagron.v37i4.19528.

Gasparin, E.; Araujo, M.M.; Zavistanovicz, T.C.; Aimi, S.C.; León, E.B.; Berghetti, A.L.P. Supervivencia y crecimiento inicial de Parapiptadenia rigida en campo. Floresta, v. 47, n. 4, p. 533-541, 2017. https://doi.org/10.5380/rf.v47i4.54234.

Gonçalves, J.L.M.; Santarelli, E.G.; Moraes Neto, S.P.; Manara, M. Produção de mudas de espécies nativas: substrato, nutrição, sombreamento e fertilização. In: Gonçalves, J.L.M.; Benedetti, V. (Eds.). Nutrição e fertilização florestal. Piracicaba: IPEF, 2005. p.309-350. 
Grings, M.; Brack, P. Espécies Madeireiras. In: Coradin, L.; Siminski, A.; Reis, A. (Orgs.). Espécies nativas da flora brasileira de valor econômico atual ou potencial: plantas para o futuro - Região Sul. 1. ed. Brasília: Ministério do Meio Ambiente, 2011. v.1, p.13934. https://www.mma.gov.br/publicacoes/biodiversidade/ category/54-agrobiodiversidade. html?download=875: especiesnativas-da-flora-nativa-de-valor-economico-atual-e-potencialplantas-para-o-futuro-regiao-sul. 02 Aug. 2019.

Grossnickle, S.C. Why seedlings survive: influence of plant atributes. New Forests, v.23, p.711-738, 2012. https://doi.org/10.1007/ s11056-012-9336-6.

Jacobs, D.F.; Landis, T.D. Fertilization. In: Dumroese, R.K.; Luna, T.; Landis, T.D. (Eds.). Nursery manual for native plants: a guide for tribal nurseries. Nursery management. v. 1. Washington: U.S. Department of Agriculture, Forest Service, 2009. 302 p. (Agriculture Handbook, 730)

Malavasi, U.C.; Malavasi, M.M. Efeito do volume do tubete no crescimento inicial de plântulas de Cordia trichotoma (Vell.) Arrab. ex Steud e Jacaranda micranta Cham. Ciência Florestal, v. 16, n. 1, p. 11-16, 2006. https://doi.org/10.5902/198050981883.

Marenco, R. A.; Lopes, N. F. Fisiologia vegetal: fotossíntese, respiração, relações hídricas e nutrição mineral. Viçosa: Ed. UFV, 2009. 486 p.

Medeiros, M.B.C.L. Índice de qualidade de Dickson e característica morfológica de mudas de pepino, produzidas em diferentes substratos alternativos. Agroecossistemas, v.10, n.1, p.159-173, 2018. https://doi.org/10.18542/ragros.v10i1.5124.

Navroski, M.C.; Berghetti, A.L.P.; Fenilli, T.A.B.; Buss, R.; Pereira, M.O.; Turchetto, F. Adubação de mudas em viveiros florestais. In.: Araújo, M.M.; Navroski, M.C.; Schorn, L.A. (Orgs.). Produção de sementes e mudas: um enfoque à Silvicultura. Santa Maria: Ed. UFSM, 2018. p. 237-258.
Oliet, J.; Segura, M.L.; Dominguez, F.M.; Blanco, E.; Serrada, E.; Arias, M.L.; Artero, F. Los fertilizantes de liberacion controlada lenta aplicados a la produccion de planta florestal de vivero. Efecto de dosis y formulaciones sobre la calidad de Pinus halepensis mil. Investigación Agraria. Sistemas y Recursos Forestales, v.28, n.1, p.207-228, 1999. https://recyt.fecyt.es/index.php/IA/article/ view/2742. 02 Aug. 2019.

Pinto, J.R.; Dumroese, R. K.; Davis, A.S.; Landis, T.D. Conducting seedling stocktype: a new approach to an old question. Journal of Forestry, v.109, n.5, p. 293-299, 2011. https://www.fs.fed.us/ rm/pubs_other/rmrs_2011_pinto_j002.pdf. 02 Aug. 2019.

Rorato, D. G.; Araujo, M. M.; Tabaldi, L. A.; Turchetto, F.; Berghetti, A. L. P.; Griebeler, A. M.; Barbosa, F. M.; Aimi, S. C. Silvicultura com espécies florestais nativas mediante o plantio de mudas: uma experiência em áreas ripárias no sul do Brasil. In.: Araújo, M.M.; Navroski, M.C.; Schorn, L.A. (Orgs.). Produção de sementes e mudas: um enfoque à Silvicultura. Santa Maria: Ed. UFSM, 2018. Cap. 17, p. 367-382.

Saueressig, D. Plantas do Brasil: árvores nativas. v.1. Irati: Ed. Plantas do Brasil, 2014. 432p.

Shapiro, S.S.; Wilk, M.B. An analysis of variance test for normality (complete sample). Biometrika, v.52, n.3, p.591-611, 1965. https://doi.org/10.1093/biomet/52.3-4.591.

Sociedade Brasileira de Ciência do Solo; Comissão de Química e Fertilidade do Solo - SBCS/CQFS. Manual de adubação e de calagem para os Estados do Rio Grande do Sul e de Santa Catarina. 10.ed. Porto Alegre, 2004. 400p

Tedesco, M.J.; Gianello, C.; Bissani, C.A.; Bohen, H.; Volkweiss, S.J. Análise de solo, plantas e outros materiais. 2.ed. Porto Alegre: Departamento de Solos; Universidade Federal do Rio Grande do Sul, 1995. 174p. (Boletim Técnico de Solos, 5). 